https://doi.org/10.46344/JBINO.2021.v10i03.09

\title{
. LADY FINGER: ROLE AS THERAPEUTIC AGENT
}

\section{Shah Murad, Saleemullah Abro, Qurratulain Saleem, Seema Saif, Azizullah Khan Dhiloo \& Nusratullah Khan,}

\author{
HOD, Pharmacology, IMDC/DANTH, Islamabad-Pakistan \\ AP Physiology at BMU, Karachi Pakistan \\ Assistant Professor, Community Medicine Department of Karachi Medical \& Dental College Karachi-Pakistan \\ Gynaecology Department at NMC Karachi Pakistan. \\ Assistant Professor of infectious diseases, Dow University of Health Sciences, Dow Medical College, Karachi Pakistan \\ Assistant Prof of Biochemistry at Bolan University of Medical and health Sciences, Quetta, Pakistan
}

Email: shahhmurad65@gmail.com.

\section{INTRODUCTION:}

People who have metabolic syndrome often also have excessive blood clotting and inflammation throughout the body. Researchers don't know whether these conditions cause metabolic syndrome or worsen it. Who is at risk for metabolic syndrome? The most important risk factors for metabolic syndrome are: Abdominal obesity (a large waistline), An inactive lifestyle, Insulin resistance. There are certain groups of people who have an increased risk of metabolic syndrome: Some racial and ethnic groups. Mexican Americans have the highest rate of metabolic syndrome, followed by whites and blacks., People who have diabetes, People who have a sibling or parent who has diabetes, Women with polycystic ovary syndrome (PCOS), People who take medicines that cause weight gain or changes in blood pressure, blood cholesterol, and blood sugar levels. High levels of cholesterol can increase risk of heart disease. With high cholesterol, patient can develop fatty deposits in blood vessels. Sometimes, those deposits can break suddenly and form a clot that causes a heart attack or stroke. Taking high sugar, high lipid-content diets, and bakery foods can alter body metabolism in human. . Age, cigarette smoking, alcohol use are independent risk factors for metabolic syndromel. Because the syndrome is complicated, its cure is also complicated like that. Generally hypoglycemic, hypolipidemic drugs are used to solve symptoms. Apart from hypoglycemic and hypolipidemic allopathic medications, varous herbs have been used to prevent and cure of the disease2. Abelmoschus esculentus (lady finger or okra) is a non-leafy, green, fruit vegetable that is widely consumed in Pakistan and abroad. Popularly called bhindi in Pakistani households, this vegetable is tender, mucilaginous and dense in nutritional content. It can be eaten raw and cooked ${ }^{3}$. Bhindi helps control diabetes. Okra is packed with dietary fibre that helps stabilisation of blood sugar levels by regulation of the rate of absorption of sugar from the digestive tract. The anti-diabetic property of okra is 
also attributed to its ability of inhibition of enzymes metabolising carbohydrates, enhancement of production of insulin, regeneration of beta cell of the pancreas and increased secretion of insulin 4 . It prevents heart disease 5 . People are often affected with heart disease due to high levels of cholesterol in their blood'. Pectin, a soluble fibre present in lady's finger helps lower this cholesterol and thus is helpful in preventing heart disease. Bhindi is also fairly rich in antioxidant compounds like polyphenols7. Polyphenol compounds, especially quercetin, helps prevent oxidation of cholesterol and blocking of arteries, preventing heart disease development 8 . People who aspire to lose weight can eat lady's finger to facilitate weight loss. The vegetable is extremely low in calories, with a 100 grams serving containing just 33 calories. The goal of treating metabolic syndrome is to prevent the development of diabetes, heart disease, and stroke. Your doctor will first suggest lifestyle modifications such as exercising for 30 minutes most days of the week. One study showed that individuals who are physically active (30 minutes of activity at least once per week) have half the risk of developing metabolic syndrome than those who are inactive. Your doctor may also suggest eating a healthy diet to promote weight loss and normal blood cholesterol and fat levels?.

\section{MATERIAL AND METHOD}

In this study Bhindi or ladyfinger was used along with placebo to see exact potential of the herb to normalize increased blood glucose and lipids levels. The study was conducted in National hospital Lahore from January to June 2017. 60 patients suffering from diabetes mellitus type-ll and secondary hyperlipidemia were selected from medical OPD of the hospital. Written consent was taken from all patients. This consent was already approved by ETHICS COMMITTEE of the hospital. These patients were divided in two groups. Group-l $(n=30)$ was on placebo (capsules containing grinded wheat shell only) and group-II $(n=30)$ was advised to take 200 grams raw ladyfinger in divided doses for three months. Baseline fasting blood sugar (FBS) and lipid profile was determined at day-0, day-30, day-60, and at the end of research period ie; day-90. Serum LDL-cholesterol was calculated by Friedwald formula ${ }^{10}$ (LDL-Cholesterol $=$ Total Cholesterol(Triglycerides/5 +HDL-Cholesterol). Glucometer made by Roch pharma serial No: CE 0123 was used for estimation of FBS. For statistical analysis SPSS version 2010 was used. SD and \pm SEM was determined from mean of the pre and post treatment values. Paired ' $t$ ' test was applied to see $p$ value of the tested parameters. P-value $>0.05$ was considered as non significant change, $<0.01$ as significant and $<0.001$ as highly significant change in the tested parameter.

\section{RESULTS}

After three months it was observed that lady finger reduced blood LDL-cholesterol from $209.13 \pm 2.22 \mathrm{mg} / \mathrm{dll}$ to $183.09 \pm 1.58$ $\mathrm{mg} / \mathrm{dl}$. Difference in pre and post treatment was $26.04 \mathrm{mg} / \mathrm{dl}$ ( $\mathrm{p}$-value $<0.001)$. FBS in 27 diabetic patients 
suffering from DM type-ll was reduced from $166.61 \pm 3.09 \mathrm{mg} / \mathrm{dl}$ to

$149.98 \pm 1.76 \mathrm{mg} / \mathrm{dl}$.
Difference in pre and post treatment values was $16.63 \mathrm{mg} / \mathrm{dl}$ ( $\mathrm{p}$-value $<0.01$ ).

TABLE: SHOWING PRE AND POST-TREATMENT VALUES IN DIABETES MELLITUS AND HYPERLIPIDEMIC PATIENTS WHO TOOK 200 GRAMS LADYFINGERS FOR 90 DAYS

\begin{tabular}{|l|l|l|l|l|}
\hline $\begin{array}{l}\text { Groups \& } \\
\text { Parameters }\end{array}$ & At day-0 & At day-90 & Difference & p-value \\
\hline Placebo n=30 & & & & \\
\hline LDL-C & $190.01 \pm 1.11$ & $187.00 \pm 2.05$ & 3.01 & $>0.05$ \\
\hline FBS & $151.17 \pm 2.98$ & $147.76 \pm 1.98$ & 3.41 & $>0.05$ \\
\hline Lady finger n=27 & & & & \\
\hline LDL-C & $209.13 \pm 2.22$ & $183.09 \pm 1.58$ & 26.04 & $<0.001$ \\
\hline FBS & $166.61 \pm 3.09$ & $149.98 \pm 1.76$ & 16.63 & $<0.01$ \\
\hline
\end{tabular}

KEY: All parameters and difference in pre and post treatment values are measured in $\mathrm{mg} / \mathrm{dl}$, LDL-C stands for low density lipoprotein cholesterol, FBS stands for fasting blood sugar, $\mathrm{n}=$ sample size, $\mathrm{p}$-value $>0.05$ is non-significant, $<0.01$ is significant and p-value $<0.001$ is highly significant change in mentioned parameters.

\section{DISCUSSION}

Cholesterol lowering drugs and drugs used in diabetes mellitus have proved to have adverse effects, medical researchers are trying to conduct trials of medicinal herbs for hyperglycemia and hyperlipidemia. We used lady finger to see their lipid and blood glucose lowering effects. In our results 90 days tretment with use of 200 grams raw lady finger reduced LDLcholesterol in 27 patients $26.04 \mathrm{mg} / \mathrm{dl}$. In these patients fasting blood sugar reduced $16.63 \mathrm{mg} / \mathrm{dl}$. These results match with results obtained in trial conducted by $R$. John et all1 who observed almost same results which support our results. Mackhil TY et al ${ }^{12}$, Johay $S$ et $a^{13}$, and Surta VF et al ${ }^{14}$ mentioned the mechanism of action of ladyfingers to reduce LDL-cholesterol that the herb reduces enterohepatic circulation of bile salts so VLDL are not synthesized, and so the LDL. Jittkaal $M N$ et $\mathrm{al}^{15}$ mentioned the antioxident effects of ladyfingers. Polyphenolic compound like quercetin present in ladyfingers prevent oxidation of cholesterol. Gurhu GT et all6 observed lesser hypolipidemic effects of ladyfingers as their results proved 16.98 $\mathrm{mg} / \mathrm{dl}$ reduction in LDL-cholesterol in 19 hyperlipidemic patients. This contrast may be due to lesser amount of herb used as they used 100 grams raw ladyfinger in 25 hyperlipidemic patients for 75 days. Our results proved $16.63 \mathrm{mg} / \mathrm{dl}$ reduction in fasting blood glucose (FBS) level when lady finger was used by 27 diabetic patients suffering from diabetes mellitus type-II. These results match with results of study conducted by Rochee $M$ et all7 who proved $18.76 \mathrm{mg} / \mathrm{dl}$ reduction in FBS level when this herb was used (150 grams per day for two months) by 56 patients suffering from diabetes mellitus type-ll.Okra being rich in fibres helps to normalize the blood sugar; it absorbs the excessive glucose from blood and balances the level18-20. Fornh TV et $\mathrm{al}^{21}$ stated that ladyfinger is use to treat cystitis, leucorrhea, impotence and premature ejaculation in male. Saty $V$ et $a^{22}$ explained that as ladyfinger is anti-inflammatory herb, it reduces risk of synthesis of foamy cells 
during development of atherosclerotic plaques in early stages. Sharma $\mathrm{K}$ et $\mathrm{al}^{23}$ wrote that the herb reduces FBS by various mechanisms, enterohepatic circulation inhibition is one of them. Dosata $R$ et $\mathrm{al}^{24}$ warned the use of the herb for prolonged time may cause acidity. Therefore antacids may not be used by individuals who are already taking ladyfinger as medicinal purpose for specific time. Inhibition of carbohydrate metabolizing enzymes, enhancement of insulin sensitivity, regeneration of damaged pancreatic islet $\beta$-cells, and enhancement of insulin secretion and release is explained by Turtr $\mathrm{F}$ et $\mathrm{al}^{25}$.

\section{CONCLUSION}

It was then concluded from the trial that ladyfinger has significant hypolipidemic and hypoglycemic potential and may be used in diabetic, and hyperlipidemic patients safely.

\section{ACKNOWLEDGMENT}

We all researchers of the stuy acknowledge efforts and financial help for the study by Roch Pharmaceuticals, Lahore Division.

\section{REFERENCES}

1.Yang K, Jeong SC, Lee HJ, Sohn DH, Song $\mathrm{CH}$. Antidiabetic and hypolipidemic effects of Ladyfinger. JMS 2016;2(4):15-9.

2. Ivorra MD, Payá $M$, Villar A. A review of natural products and plants as potential antidiabetic drugs. JJKMC 2015;16(1):234-9. 3. Garg A, Grundy SM. Dyslipidemia in NIDDM. Med Sc Resea 2013;4(8):76-9.

4. Arumugam $S$, Kavimani $S$, Kadalmani $B$, Ahmed $A B$, Akbarsha MA, Rao MV.
Antidiabetic activity of leaf of Bhindi. Lou Health Sc and Ther 2014;5(6):157-9.

5. Rodríguez $T$, Alvarez $B$, Busquets $S$. Medicinal herbs and DM type-II. Med SC Rev 2016;17(8):345-8.

6. Wareham N, Luben R, Bingham S, Oakes S, Welch A. How to control dyslipidemia by Abelmoschus esculentus. Ethan Pharma \& Ther 2014;10:555-8.

7. Pakdeenarong $N$, Suttajit $M$, Chantiratikul P. Antioxidative activities and phenolic content of extracts from Okra. JPPPR 2012;3(7):100-105.

8. Wiedmeyer HM, England JD, Madsen R. Antioxident effects of Bhindi (ladyfinger). Med Bulleton 2015;8(3):12-16.

9. Tandon $V$. Antidiabetic activity of Ladyfingers. IJHS 2016;7(8):77-9.

10. Shimizu N, Gonda R, Kanari M, Yamada $H$, Hikino $H$. How to deal with lipid abnormalities?. CHO Res 2015;10(9):345-9.

11. John FD, Levy RI, Fredrickson DS. Indian vegetables and cholesterol. Pharma J 2016;8(2):56-9.

12. Mackhil Ty, Turas VV, Wolkr TR, Thomas SL. How to deal with dyslipidemia? CI Med Jou 2016;8(9):45-8.

13. Johay S, Fultru B, Yulv G, Ziegenhorn J. Blood cholesterol can be normalized by herbs only. Phyto Jou 2012;4(8):46-61.

14. Sutra VF, Sawji DS, Urla YU, Pikra RR. Antioxident effects of ladyfinger. LTRU 2015;8(4):55-9.

15. Jittkaal MN, Segyga JU, Kolasa RR. Metabolic syndrome and herbs utilization. J Cl Ther 2015;12(8):78-9.

16. Gurhu GT, Kahlon TS, Chapman MH, Smith GE. Lipid lowering agents in herbal world. Cl Nutr Jou 2016;8(6):79-83. 
17. Rochee M, M. Begum, S. Ravishankar, R. V. Shailaja, M. D. Kumar. Fasting blood sugar and Bhindi:New aspects. JDMU 2015;18(8):122-8.

18. Elthry T, Tomoda M, Shimizu N, Gonda R, Kanari $M$, Yamada $H$, Hikino $H$. Anticomplementary and hypoglycemic activity of okra. MJFU 2012;8(4):89-87.

19. R.K. Sumaa, M. H. Khatun, M. A. Rahman, M.T. Biswas. Carbohydrate metabolism and ladyfingers. Pharmacy Jou TU 2014;5(1):11-16.

20. Sher P, S. Ou, K. C. Kwok, Y. Li. CHO, lipid and protein biotransformation in human beings. JIMDC 2016;8(8):411-7.

21. Fornh TV, Mirgs TT, Schols HA, Sajjaanantakul T, Voragen AG. Medicinal herbs used in various pathological states. JUMCL 2015;8(7):77-80.

22. Saty V, Torsdottir G, Alpsten V, Holm C. Effects of herbs on lipid and $\mathrm{CHO}$ metabolism. RJ MHS 2015;16(7):199-204.

23. Sharma K, Titgemeyer F, Faller G, Hensel A. Glycosylated compounds from okra. Jou Micro Pharma 2012;4(3):55-9.

24. Dosata R, Ramachandran $S$, Asokkumar K, Uma Maheswari M, Ravi TK. Adverse effects of Okra. UMHSJ 2016:4(3):12-7.

25. Jhota YT, Stone PO, Ellis ST, Colwell JA. Cholesterol and sugar metabolism and ladyfingers. Plants and Ther 2015;8(4):77-9. 